\title{
The Effect of Company Policy and Organizational Culture on Employee Engagement through Levels Job Satisfaction at PT Ecogreen Oleochemicals
}

\author{
Edward $^{1}$, Indrayani ${ }^{2}$, I Wayan Catra Yasa ${ }^{3}$ \\ ${ }^{1}$ Postgraduate Student, Department of Management, Faculty of Economics, Universitas Batam, Batam, \\ Indonesia \\ ${ }^{2-3}$ Postgraduate Lecturer, Department of Management, Faculty of Economics, Universitas Batam, Batam, \\ Indonesia
}

Corresponding Author: Edward

\begin{abstract}
The method used in this study is a causal model survey method, collecting data using a questionnaire that was prepared in advance and distributed to 100 respondents. Analysis of parametric and non-parametric statistical data, using Structural Equation Modeling-Partial Least Square regarding research variables, instrument testing, normality testing, hypothesis testing, and discussion of hypothesis testing and path analysis results. This study uses path analysis to examine the pattern of relationships that reveal the effect of a variable or set of variables on other variables, both direct and indirect effects, assisted by Smart PLS Ver 3.0 software. The results in this study indicate that: 1) Company Policy directly has a positive and significant effect on Employee Satisfaction with a p-value of $0,002<0,05,2$ ) Company Policy directly has an insignificant effect on Employee Engagement with a p-value of $0.126>0.05,3$ ) Organization Culture directly has a positive and significant effect on Employee Satisfaction with a p-value of $0.000<0.05,6)$ Company Policy with Employee Satisfaction as mediation has a positive and significant effect on Employee Engagement with a p-value of $0.030<0.05,7$ ) Organization Culture with Employee Satisfaction as mediation has a positive and significant effect on Employee Engagement with a p-value of $0.003<0.05$.
\end{abstract}

Keywords: Company Policy, Organization Culture, Employee Satisfaction, Employee Engagement.

\section{INTRODUCTION}

In general, Southeast Asian nations have a reputation for high levels of employee engagement. According to a Qualtrics study conducted in 2020 (HRMAsia, 2020), India has the most excellent level of employee engagement worldwide, at 79 per cent, followed by Thailand at 72 per cent and Hong Kong at 63 per cent. However, this is the polar opposite of the Indonesian situation, as Crabtree (2013) reported that the proportion of engaged workers in Indonesia is just 8\%, while $77 \%$ of employees are disengaged, and $15 \%$ are actively disengaged. In today's industrial environment, human resources are critical assets that contribute directly to the advancement and sustainability of business via human resource optimisation.

In today's business world, human resources are not only viewed as an employee whose sole purpose is to perform work or support functions but also as an asset owned by the company that contributes to the organisation's success in achieving its vision and mission, allowing the business to operate continuously on occasion. Essentially, any organisation or corporation desires maximum earnings and the ability to sustain the firm over an extended time.

Today's business faces unique challenges due to the 4.0 industrial 
revolution, which has brought artificial intelligence and the internet into the industrial world, requiring businesses to be prepared to optimise enterprise needs by carefully preparing for quality human resources. Human resources are a critical component in carrying out the company's operations. Human resources, as previously stated, are assets that must be managed appropriately to maximise their contribution to the company's growth and sustainability. One of the factors that a business must examine in order to accomplish this objective is the degree of employee engagement. When it is discovered that workers are not comfortable at work, are not acknowledged or recognised for their presence, and cannot develop their abilities, they will immediately lose focus on the task at hand.

The industry must consider this in order to maximise these employees' level of engagement with the organisation. When it is discovered that employees work unsatisfactorily, lack respect, and are not provided with opportunities to develop their potential, employees will mentally disengage from their employment. Enhancement employee involvement in the sector, sound business policies and a healthy organisational culture are required. This scenario is advantageous for achieving high levels of work satisfaction, which ultimately results in increased employee engagement. This case also has a detrimental effect on employee conduct in other instances, such as subjective yearly performance evaluations or staff promotions. In this instance, corporate policy may refer to a director's decision or company regulations promoting uniformity and discipline in managing business interactions. As a result, continual changes to business rules that foster employee engagement are necessary.

The prevalent occurrence in private businesses is that many behaviours vary from the normative rules controlled inside the organisation. Regulated corporate policies should not be less stringent than the government-regulated normative standards.
For instance, if the government established a minimum wage, employers would be banned from paying less than the minimum wage. Adhering to these corporate rules demands a business owner's dedication. If business rules vary from and are less stringent than regulatory requirements, employee participation will not occur and will have deadly repercussions if not addressed quickly. Additionally, it is suggested that the created business policy be distributed to workers monthly to ensure that employees always understand the policy's objective and prevent future misunderstandings. On the other hand, organisational culture is inextricably linked to the leader's figure and the interpersonal connections amongst workers. Leaders play a critical role in fostering harmony among their subordinates, ensuring that crossdepartmental collaboration runs smoothly, and becoming one of the primary factors influencing employee job satisfaction. Job satisfaction is one of the consequences of employee performance; job satisfaction affects whether a person performs at a high or poor level. Job satisfaction is anticipated to enhance employee performance and contribute to the achievement of positive performance outcomes.

Employee engagement is a critical asset for an organisation's continued success. Employee engagement may result in less absenteeism and turnover, increased revenue, and increased productivity. In this case, poor employee engagement becomes a broader business issue since workers spend more time at work, yet if the job is meaningless, this may have a detrimental effect on employee well-being (Hulin, 1998). According to past research, there is a strong correlation between work satisfaction and employee engagement. However, in the industrial sector, there is no universally accepted method for boosting employee engagement. Thus, this study aims to provide an overview of sound corporate policies and healthy organisational culture in an oleochemical manufacturing company established in Batam in 1991 and produces 
Saturated Fat Alcohols (from C-8 to C-18), Unsaturated Fat Alcohols, Oleic Acids, Refined Glycerin, and Special Esters.

\section{LITERATURE REVIEW}

The policy of the company

According to Islam, a policy is distinct from knowledge. Further examination of the policy concept is necessary since a policy includes the regulations included within it (Suandi, 2010). Anderson explains that a policy is a planned course of action taken by an actor or group of actors in response to an issue or concern (Islamy, 2009). Anderson's policy idea is better since it is centred on what is being done rather than on what is planned or intended. Furthermore, this term distinguishes clearly between policy and choice, which refers to the process of selecting from a variety of options.

\section{Culture of the organisation}

Organisational culture is a collection of assumptions or systems of ideas, values, and conventions established inside an organisation to influence its employees' conduct in overcoming external and internal adjustment issues (Mangkunegara, 2015). According to Schein, culture is a set of fundamental assumptions made, discovered, or developed by a particular group as a means of overcoming external adaptation and internal integration challenges that are formal and well-implemented and thus taught or passed on to new members as an appropriate mode of understanding, considering and feeling about the occurrence of an issue (Yuswani, 2016). Organisational culture is the collective beliefs, attitudes, and values inside the organisation; or, to put it another way, culture is how we do things (Sedarmayanti, 2018).Seven distinct characteristics together describe the nature of organisational culture (Sudarmanto, 2014), namely:

- Innovation and Courage to Take Risks is the extent to which employees are encouraged to be innovative and dare to take risks.
- Attention to detail is the extent to which employees exercise precision, analysis, and attention to detail.

- Outcome Orientation is the extent to which management focuses more on results than on the techniques and processes used to achieve those results.

- People Orientation, i.e. the extent to which management decisions consider the effects of employee outcomes in the organisation.

- Team Orientation is the extent to which employees' activities are on the team rather than on individuals.

- Aggression is the extent to which people are innovative, aggressive and competitive.

- Stability is the degree to which an organisation's activities emphasise maintaining the status quo concerning the company's growth.

\section{Job satisfaction}

Job satisfaction is: the appraisal of one's job as attaining or allowing the attainment of one's essential job values, providing these values are congruent with or help fulfil one's basic needs (Edwin, 1968). Job satisfaction is a positive feeling about a job that results from a clear assessment of its characteristics (Robbins \& Coulter, 2018). Job satisfaction must be created and maintained so that employee morale, discipline, and performance can increase. Job satisfaction in employment is satisfaction obtained in the workplace in praise, adequate facilities, attention from management and the atmosphere or climate on the job. There are several indicators of job satisfaction (Colquitt, Jeffrey, \& Wesson, 2009), namely:

1. As a multidimensional factor in job satisfaction, salary is the number of wages or money received and the level at which this can be seen as something that is considered appropriate compared to others in the organisation. Money helps people obtain basic needs and is also a tool to provide satisfaction needs at a higher level. 
2. Promotion is a career opportunity to advance in an organisation. It seems to have a different effect on job satisfaction. This case is because promotions come in different forms and have awards, such as promotions based on seniority or performance and promotions for pay raises.

3. Supervision is the ability of superiors to provide technical assistance and behavioural support to subordinates. There are 2 (two) dimensions of supervisory style that can affect job satisfaction, namely:

a. Employee-centered, measured by the degree to which it uses personal interest and concern for employees, such as providing advice and assistance to employees, good communication and researching how well employees work

b. Influence in decision making can affect the work of employees. In general, these two dimensions have a significant influence on employee job satisfaction.

4. In general, co-workers who are cooperative and have a high level of teamwork are the most straightforward source of job satisfaction for individual employees. Working groups, especially 'strong' teams, act as a source of support, comfort, advice, and assistance to individual members. Because the working group is interdependent between members in completing the work, such conditions effectively make work more enjoyable, thus bringing a high positive effect on job satisfaction.

5. Satisfaction with the job itself is a significant source of satisfaction, where the job provides a good job, the opportunity to learn, the opportunity to accept responsibility and progress for employees.

6. Altruism is a voluntary act performed by a person or loyalty or dedication to an organisation or company.

7. Status is one of the factors that can affect job satisfaction. The status classified in several ways, such as skills \& expertise, duration of the training, amount of social responsibility or work attitude, can affect individual job satisfaction.

8. The social environment consists of the physical and psychological work environment. Employees will be able to work and complete their work if the surrounding conditions are clean, bright, not too narrow and noisy so that employees will efficiently work and complete the work in a harmonious atmosphere or condition.

\section{Employee Engagement}

Employee participation or employee engagement was first introduced by Kahn (1990), with three principal characteristics, namely physical, cognitive, and emotional. The first feature of employee engagement is the physical aspect, referred to as the physical energy of an individual employee's efforts to complete his or her tasks in the organisation. As the second aspect of employee participation, cognition refers to employees' beliefs about the organisation, leaders, and working conditions. Finally, the emotional aspects of employees refer to the organisation, leaders, and working conditions. This aspect can be the positive or negative attitude of the employees towards the organisation and its leaders. Employees who engage will desire to be committed that ultimately engenders a passion for their work, are committed to their work, are willing to sacrifice more energy and time for their work and become more proactive in achieving their work goals. The following are the dimensions and indicators of employee engagement.

a. Spirit Indicators: Willingness to work, work ethic, contribution.

b. Dedication Indicators: Enthusiasm, Inspiration, Pride

c. Absorption Indicators: Concentration, Time, Difficulty

\section{RESEARCH METHOD}

Data collection was done using several data sources, namely collecting primary data obtained using questionnaires 
as research instruments and secondary data collection, which is data obtained from graphic documents (tables, diaries, photographs, films, video recordings, objects). The population in this study was 130 people and, by using the Slovin formula with a standard error of $5 \%$, we obtained a sample size of 100 respondents. Data analysis techniques used in this study use quantitative testing with SmartPLS Version 3.0 tools.

Accordingly, we propose the following research hypotheses.

H1: Company policies have a direct impact on job satisfaction.

$\mathrm{H} 2$ : Organisational culture has a direct influence on job satisfaction.

H3: Job satisfaction has a direct effect on employee engagement.

H4: Job satisfaction has a direct effect on employee engagement.

H5: Organisational culture also directly affects employee engagement.

H6: Company policies can affect employee engagement indirectly through job satisfaction.

H7: Organisational culture can affect employee engagement indirectly through job satisfaction.

\section{RESULT}

Respondent characteristics in this study measured based on age 18-25 years old as 35 people with a percentage of $26 \%$ respondents based on city of origin come from Medan City as many as 36 people with a percentage of $27 \%$ respondents based on gender men as many as 94 people with a percentage of $72 \%$ respondents have the position of Rank \& File as many as 95 people with a percentage of 72 In order to test the construct of the statement that will be distributed to the respondents, an outer model test is performed, namely, a reliability test. The reliability results are based on the AVE value.

\begin{tabular}{|c|c|c|c|c|}
\hline \multicolumn{5}{|c|}{$\begin{array}{l}\text { Table 1. Out } \\
\text { Cronbach' }\end{array}$} \\
\hline & s Alpha & & Reliability & \\
\hline $\begin{array}{l}\text { Company } \\
\text { policy }\left(\mathrm{X}_{1}\right)\end{array}$ & 0,838 & 0,791 & 0,803 & 0,407 \\
\hline $\begin{array}{l}\text { Organizational } \\
\text { culture }\left(\mathrm{X}_{2}\right)\end{array}$ & 0,761 & 0,799 & 0,823 & 0,443 \\
\hline $\begin{array}{l}\text { Job satisfaction } \\
(\mathrm{Y})\end{array}$ & 0,938 & 0,940 & 0,951 & 0,764 \\
\hline $\begin{array}{l}\text { Employee } \\
\text { engagement (z) }\end{array}$ & 0,957 & 0,959 & 0,964 & 0,795 \\
\hline
\end{tabular}

Internal consistency analysis above obtained the result that variable $\mathrm{X} 1$ has a composite reliability value of $0.803>0.600$, variable $\mathrm{X} 1$ is reliable, variable $\mathrm{X} 2$ has a composite reliability value of $0.823>0.600$, variable $\mathrm{X} 2$ is reliable, variable $\mathrm{Y}$ has a composite reliability value of $0.95>0.600$, variable $\mathrm{Y}$ is reliable, variable $\mathrm{Z}$ has a composite reliability value of $0.964>0.600$, variable $\mathrm{Z}$ is reliable. While the results of the validity test are as follows:

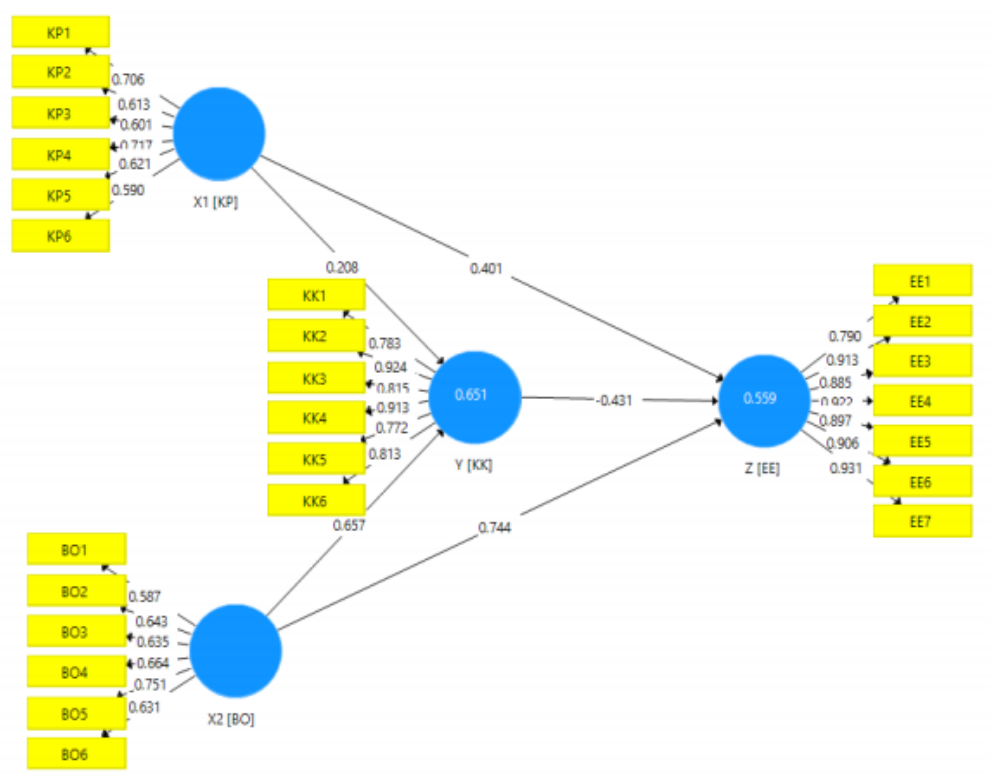

Figure 1. Loading Factor 
Based on the picture above, the value of each statement construct is obtained at a value greater than 0.5 . It is stated that all questionnaires are valid. The results of the outer model indicate that the distributed questionnaires have met the requirements of validity and reliability. The inner model can then be tested using the collinearity test and the significance of the structural model path coefficient. The results of the collinearity test are as follows.

Table 2. Collinearity Tests

\begin{tabular}{|l|l|l|l|l|}
\hline Variable & $\mathbf{X}_{\mathbf{1}}$ & $\mathbf{X}_{\mathbf{2}}$ & $\mathbf{Z}$ & $\mathbf{Y}$ \\
\hline $\mathbf{X}_{\mathbf{1}}$ & & & 1,680 & 1,938 \\
\hline $\mathbf{X}_{\mathbf{2}}$ & & & 1,680 & 2,494 \\
\hline $\mathbf{Y}$ & & & & 2,656 \\
\hline $\mathbf{Z}$ & & & & \\
\hline
\end{tabular}

Based on table 4.8 above can be described as follows:

a. The VIF for the correlation of X1 with $\mathrm{Z}$ was $1,938<5.00$ (no collinearity problems occurred);

b. The VIF for the correlation of X2 with $\mathrm{Z}$ was $2.494<5.00$ (no collinearity problems occurred);

c. The VIF for $\mathrm{Y}$ to $\mathrm{Z}$ correlation was $2,656<5.00$ (no collinearity issues).

In this test, there are two stages: testing the hypothesis of direct influence and testing the hypothesis of indirect influence. Testing the direct influence hypothesis aims to prove the hypothesis of the influence of one variable on other variables directly (without mediation).

\section{Direct Effect}

\begin{tabular}{|c|c|c|c|c|c|}
\hline & $\begin{array}{l}\text { Original } \\
\text { Sample }\end{array}$ & $\begin{array}{l}\text { Sample } \\
\text { Mean }\end{array}$ & $\begin{array}{l}\text { Standard } \\
\text { Deviation }\end{array}$ & T Statistics & P Values \\
\hline Company Policy $\rightarrow$ Job Satisfaction & 0,312 & 0,326 & 0,099 & 3,157 & 0,002 \\
\hline Company Policy $\rightarrow$ Employee Engagement & 0,148 & 0,164 & 0,097 & 1,520 & 0,128 \\
\hline Organizational Culture $\rightarrow$ Job Satisfaction & 0,554 & 0,551 & 0,090 & 6,128 & 0,000 \\
\hline Organizational Culture $\rightarrow$ Employee Engagement & 0,284 & 0,292 & 0,098 & 2,905 & 0,004 \\
\hline Job Satisfaction $\rightarrow$ Employee Engagement & 0,480 & 0,460 & 0,142 & 3,388 & 0,001 \\
\hline
\end{tabular}

The direct effect of company policy variables on job satisfaction variables has a path coefficient of 3,157 (positive), then the increase in the value of company policy variables will be followed by an increase in job satisfaction variables. With a P-Value of $0.002<0.05$ for the effect of company policy variables on job satisfaction, it can be stated that the effect of company policy on job satisfaction is significant.

The direct effect of company policy variables on employee engagement variables has a path coefficient of 1,520 (positive), then the increase in the value of company policy variables will be followed by an increase in employee engagement variables. The effect of company policy variables on employee engagement has a $\mathrm{P}$ Values value of $0.128>0.05$, so it can be stated that the effect of company policy on employee engagement is not significant.

The direct effect of organisational culture variables on job satisfaction variables has a path coefficient of 6,128 (positive), then the increase in the value of organisational culture variables will be followed by an increase in job satisfaction variables. The influence of organisational culture variables on job satisfaction has a PValues value of $0.000<0.05$, so it can be stated that the influence of organisational culture on job satisfaction is significant.

The direct effect of organisational culture variables on employee engagement variables has a path coefficient of 2,905 (positive), then the increase in the value of organisational culture variables will be followed by an increase in employee engagement variables. The influence of organisational culture variables on employee engagement has a P-Values value of $0.004<0.05$, so it can be stated that the influence of organisational culture on employee engagement is significant.

The direct effect of job satisfaction variables on organisational culture variables has a path coefficient of 3,388 (positive), then the increase in the value of job 
satisfaction variables will be followed by an increase in organisational culture variables. With a P-Values value of $0.001<0.05$ for the influence of job satisfaction on organisational culture, it can be stated that the effect of job satisfaction on organisational culture is significant.

\section{Indirect Effect}

\begin{tabular}{|c|c|c|c|c|c|}
\hline & $\begin{array}{l}\text { Original } \\
\text { Sample }\end{array}$ & $\begin{array}{l}\text { Sample } \\
\text { Mean }\end{array}$ & $\begin{array}{l}\text { Standard } \\
\text { Deviation }\end{array}$ & $\begin{array}{l}\mathbf{T} \\
\text { Statistics }\end{array}$ & $\begin{array}{l}\mathbf{P} \\
\text { Values }\end{array}$ \\
\hline Company Policy $\rightarrow$ Job Satisfaction $\rightarrow$ Employee Engagement & 0,150 & 0,151 & 0,068 & 2,198 & 0,028 \\
\hline Organisational Culture $\rightarrow$ Job Satisfaction $\rightarrow$ Employee Engagement & 0,266 & 0,254 & 0,089 & 2,973 & 0,003 \\
\hline
\end{tabular}

Based on the table 4 of Indirect Effect Hypothesis above can be compared. The previous direct effect of company policy on employee engagement was 1,520, which is less than the indirect effect of company policy on employee engagement through job satisfaction, worth 2,198. With the presence of job satisfaction variables as a mediation between company policy variables and employee engagement, the value strengthens so that it can be stated that job satisfaction is a full mediation between company policy variables and employee engagement. The previous direct effect of organisational culture on employee engagement was 2,905 , smaller than the indirect effect in the table above of organisational culture on employee engagement through job satisfaction, worth 2,973 . With the presence of job satisfaction variables as a mediator, the value strengthens so that it can be stated that job satisfaction is a full mediation between the variables of organisational culture and the variables of employee engagement, while the test results of the coefficient of determination are as follows.

Table 5. R Square

\begin{tabular}{|l|l|l|}
\hline & R Square & R Square \\
\hline Job Satisfaction & 0.624 & 0.619 \\
\hline Employee Engagement & 0.686 & 0.676 \\
\hline
\end{tabular}

In the table 5 above, the result of the influence of company policy and organisational culture on $\mathrm{Y}$ is 0.624 , meaning the magnitude of the influence of company policy and organisational culture on the variable $\mathrm{Y}$ is $62.4 \%$ and $37.6 \%$ influenced by other variables not included in this study. Then the effect of company policy and organisational culture on employee engagement is 0.686 , meaning the amount of influence of company policy and organisational culture on employee engagement variables is $68.6 \%$, and $31.4 \%$ is influenced by other variables not raised in this study.

\section{DISCUSSION}

This research is partly in line with the theory developed previously. Some are not because the employee participation variable (employee engagement) is still relatively new but still in line and supports the theory developed in the previous chapter on the four variables associated with the object of this research. Company policy is an essential strategy in any company that organises and becomes the focus of management in running the business or carrying out the mission - the mission of the company to achieve the vision that has been set for the company's progress.

Superiors and subordinates are also required by company policy to express their feelings about any action, such as disciplinary action. Organisational culture is the accumulation of actions taken from time to time by stakeholders in every decisionmaking by management for its employees to guide them to achieve company goals. Therefore, organisational culture is needed to direct the behaviour of employees in the company to be more positive to achieve the company's goals. As evidenced by the findings, job satisfaction is expected to mediate in this study; however, job satisfaction obtained results cannot mediate 
between variables but can still positively affect different variables. Job satisfaction is needed to maintain morale and motivate employees. Employee Engagement is required to provide a portrait of the condition, attitude, and behaviour of employees toward their work as demonstrated by work ethic, dedication, and enthusiasm in order to create a supportive environment for each employee to develop himself, and by developing himself, future management development is expected. The company can achieve long-term viability.

This study has some limitations that may disrupt the research results. The limitations include: This research data is generated from an instrument built from theory by looking at existing phenomena and then developed into question items based on respondents' answers in the form of a Likert scale. This case causes many problems, among them psychologically; the respondents answer the questionnaire to contain a very high subjective element. Furthermore, this study is based on a survey method using questionnaires rather than interviews due to the pandemic conditions.19. Researchers have not been able to conduct interviews with all respondents. The conclusions are drawn only based on data collected through tabulations managed using data path analysis tools. The researcher and the respondent do not interact directly or create a relationship and interaction in-depth in interpreting the research for developing theory in the future. The research also has limitations on the time and cost required to make this research more complete. It is hoped that future research will be more in-depth and comprehensive.

\section{CONCLUSION}

With a positive value path coefficient, company policy has a positive effect on job satisfaction, and an increase follows an increase in the value of company policy for job satisfaction. The influence of Company Policy variables on Job Satisfaction has a P-Values value smaller than the specified standard, so it can be concluded that the influence of Company Policy on Job Satisfaction is significant. Companies need to pay attention to the application of company policies because, based on this research, employees are dissatisfied with company policies, which also has a direct or indirect effect on employee engagement.

Company policies have a positive effect on employee engagement, with a positive value path coefficient. Then, the increase in the value of the Company Policy variable will be followed by an increase in the Employee Engagement variable. The influence of Company Policy on Employee Engagement has a P-Values value more significant than the specified standard, so it can be concluded that the influence of Company Policy on Employee Engagement is insignificant. The company must also implement company policies strictly but still pay attention to the welfare of its employees because, in a better-developed company, it is undoubtedly run by employees in the company itself.

Organizational Culture has a positive effect on the Job Satisfaction variable with a positive value path coefficient. Then, the increase in the value of the Organizational Culture variable will be followed by an increase in the Job Satisfaction variable. The influence of Organizational Culture variables on Job Satisfaction has a P-Values value smaller than the specified standard, so it can be concluded that the influence of Organizational Culture on Job Satisfaction is significant. According to this research, organisational culture is very influential and can affect job satisfaction and employee participation (employee engagement), both of which positively affect these two variables.

Organizational Culture has a positive effect on the Employee Engagement variable with a positive value path coefficient. Then, the increase in the value of the Organizational Culture variable will be followed by an increase in the Employee Engagement variable. The Influence of 
Organizational Culture on Employee Engagement has a P-Values value smaller than the specified standard, so it can be concluded that the influence of Organizational Culture on Employee Engagement is significant. The company is expected to create a healthy organisational culture so that employees who work in the company can apply the values that the company expects to be applied for the better development of the company.

Job satisfaction has a positive effect on the Employee Engagement variable with a positive value path coefficient. Then, the increase in the value of the Job Satisfaction variable will be followed by an increase in the Employee Engagement variable. The effect of the Job Satisfaction variable on Employee Engagement has a P-Values value smaller than the specified standard, so it can be concluded that the effect of Job Satisfaction on Employee Engagement is significant. Companies can reduce turnover rates by increasing employee job satisfaction and participation, and employees will be more motivated and loyal to the company, including a good work culture and employee welfare.

Company policy on the Employee Engagement variable, mediated by Job Satisfaction, has a positive effect with a positive value path coefficient, and the indirect effect is also positive and strengthens from the previous direct influence. The Job Satisfaction variable has a Full Mediation role on both variables because indirect variable tests are more robust than direct value tests.

Organizational Culture on Employee Engagement mediated by Job Satisfaction positively affects a positive value path coefficient. Then, the indirect determination is also positive and strengthens from the previous direct influence value. Therefore, the Job Satisfaction variable has a Full Mediation role in both variables because the value of testing for such indirect variables is more robust than testing for direct values.

\section{Conflict of Interest: None}

\section{Source of Funding: None}

\section{REFERENCES}

1. Aspan, H., Wahyuni, E. S., Effendy, S., Bahri, S., Rambe, M., \& Saksono, F. (2019). The Moderating Effect of Personality on Organizational Citizenship Behavior: The Case of University Lecturers. International Journal of Recent Technology and Engineering (IJRTE), 412-416.

2. Colquitt, J., Jeffrey, A., \& Wesson, M. (2009). Organisational, International Edition. New York: McGraw Hill.

3. Edwin, L. (1968). Toward a Theory of Tasks Motivation and Incentives. American Institutes for Research, No. 3, 157-189.

4. Hasibuan, S. (2017). Manajemen Sumber Daya Manusia. Jakarta: Bumi Aksara.

5. Hulin, C. (1998). Adaptation, Persistence and Commitment in Organization. Handbook of Industrial and Organizational Psychology, 445-505.

6. Indrayani, \& Al Qarny, A. (2020). Factors Affecting Work Satisfaction and Employee Performance in Automotive Industrial Chain. International Journal of Economics and Business Administration, Volume VIII, Issue 2, 317-325.

7. Islamy, M. I. (2009). Prinsip-Prinsip Perumusan Kebijaksanaan Negara. Jakarta: Bumi Aksara.

8. Kaddafi, M., Wahyuddin, H., Falahuddin, \& Maulida, R. (2018). Effect of Corporate Governance Mechanism, Independence and Management of Earnings Integrity of Financial Statements. Journal Quality Access, Vol. 19 No 164.

9. Mangkunegara, A. (2015). Evaluasi Kinerja Sumber Daya Manusia. Bandung: Refika Aditama.

10. Robbins, S., \& Coulter, M. (2018). Manajemen. Jakarta: Erlangga.

11. Rumengan, J., Juliandy, A., Khaddafi , M., \& Rumengan, A. (2019). Research Method. Batam: Sefa Bumi Persada.

12. Sedarmayanti. (2018). Manajemen Sumber Daya Manusia Reformasi Birokrasi Dan Manajemen Pegawai Negeri Sipil. Bandung: Refika Aditama.

13. Setiadi, N. (2017). Perilaku Konsumen. Jakarta: Kencana Pedana Media Grup.

Acknowledgement: None 
Edward et.al. The effect of company policy and organizational culture on employee engagement through levels job satisfaction at PT Ecogreen Oleochemicals.

14. Suandi, I. (2010). Eksistensi Kebijakan Publik dan Hukum Dalam Pemerintahan Daerah. Jurnal Ilmiah Fakultas Ilmu Sosial dan Ilmu Politik Universitas Udayana bali, Vol.I No. 01.

15. Sudarmanto. (2014). Budaya Organisasi dan Peningkatan Kinerja Perusahaan. Jakarta: Bumi Aksara.

16. Sugiyono. (2018). Metode Penelitian Bisnis. Bandung: Alfabeta.

17. Wahyuni, E., Fachrudin, K., \& Silalahi, A. (2019). An Empirical Study on Women's Financial Behavior: Case Study of Female Postgraduate Students in Medan, Indonesia. International Journal of Research Culture Society, 3(11), 155-159.

18. Wibisono, C., Nurhatisyah, \& Gustiawan, F. (2018). Work motivation and leadership on the performance of employees as predictors of organisational culture in the broadcasting commission of Riau Islands province, Indonesia. Management Science Letters, 247-258.

19. Winardi. (2016). Kepemimpinan dalam Manajemen. Jakarta: Rhineka Cipta.
20. Wirawan. (2015). Evaluasi Kinerja Sumber Daya Manusia (Teori, Aplikasi, dan Penelitian). Jakarta: Salemba Empat.

21. Yasa, I., Akbar, M., \& Lauluddin, M. (2019). The Effect of Cultural Family, Conflict management and Tolerance interreligious harmony stability of people in Batam. Harmony stability of people in Batam harmony stability of people in Batam.

22. Yuswani, W. (2016). Pengaruh Budaya Organisasi dan Stress Terhadap Motivasi Kerja Dan Dampaknya Terhadap Kinerja Karyawan Pada PT. Kerinci Pertama Motor Jambi. Jurnal Sainstech Politeknik Indonusa Surakarta.

How to cite this article: Edward, Indrayani, I Wayan Catra Yasa. The effect of company policy and organizational culture on employee engagement through levels job satisfaction at PT Ecogreen Oleochemicals. International Journal of Research and Review. 2021; 8(7): 286-295. DOI: https://doi.org/10.52403/ijrr.20210740 